\title{
Šventė Vilniuje: Naujieji metai lietuvių, lenkų ir rusų šeimose
}

\author{
ŽILVYTIS ŠAKNYS \\ Lietuvos istorijos institutas, Etnologijos skyrius, Kražių g. 5, LT-01108 Vilnius \\ El. paštas: shaknys@gmail.com
}

\begin{abstract}
Straipsnyje, remiantis stebejimu, anketavimu ir pusiau reglamentuoto interviu duomenimis, taip pat istorinio lyginamojo ir interpretacinio metodų teikiamomis galimybèmis, siekiama atskleisti Naujujų metų šventès etninius ir kultūrinius savitumus. Palyginsime lietuvių, lenkų ir rusų šeimose švenčiamos šventès dalyvių sudètį, šventimo vietą, šventines vaišes, šeimoje palaikomas naujametines tradicijas, ateities spejjimus ir šventès vietą ritualinių metų struktūroje.
\end{abstract}

Raktažodžiai: Vilnius, Naujieji metai, švente, lietuviai, lenkai, rusai

\section{IVADAS}

Pasak Jeremy Boissevain, vienas tradiciškiausių ir efektyviausių būdų pabrèžti grupès tapatumą yra jos nariams švęsti šventę arba kartu atlikti ritualą. Tai darant galima išsiskirti iš kitų grupių narių ir tarpusavyje pasijusti „namie“ [3,12; cit. iš 29, 37]. Simbolinè „namų“ sąvoka globalios modernybès sąlygomis ịgyja daugiareikšmị skambesị ir ịkūnija žmogui tai, kas yra svarbu. Šiuolaikinèje visuomenèje ne visada šventę galime sieti su religingumu ar iš kartos i kartą perduodama tradicija. Kaip pažymėjo Rasa Paukštytė-Šaknienė, Erico Hobsbawmo sąvoka „išrastos tradicijos“ (invented traditions) [7, 263-308] galima nusakyti ir socialistinių ritualinių metų kūrimą sovietinejje Lietuvoje [16, 208]. Kita vertus, 2005 m. tyrimai Punsko ir Seinų lietuviškose vietovèse rodo siekị perimti kai kurias sovietmečiu modifikuotas „lietuviškas šventes" ir deklaruoti etninio tapatumo prioritetą prieš vietinį ar pilietinį [23, 113-114]. Tai skatina prisiminti Fredriko Bartho žodžius apie socialiai konstruojamas etninès grupès ribas, paremtas kontaktais su kitomis etninemis grupèmis ir tais bruožais, kurie tų grupių nariams yra svarbūs $[2,9-38 ; 14]$. Taigi etninès grupès sampratą galima būtų susieti su kalendorine švente, kurios „etniniai bruožai“ dažniausiai deklaruojami daugiaetninèje aplinkoje ieškant, perimant ar sukuriant realius ar ịsivaizduojamus išskirtinius šventès savitumus. Šią prielaidą pabandysiu patikrinti tyrimu daugiataučiame Vilniaus mieste lygindamas trijų gausiausių miesto etninių grupių - lietuvių, lenkų ir rusų - švenčiamus Naujuosius metus (1). Toks tyrimas šiuolaikiniame mieste dar nebuvo atliktas.

(1) Straipsnis parengtas vykdant 2012-2014 m. temą „Šiuolaikinès vilniečių šventės šeimoje“ pagal Lietuvos mokslo tarybos Nacionalinę lituanistikos plètros 2009-2015 metų programą (sutartis LIT-5-6, vadovė dr. Rasa Paukštytė-Šaknienè, vykdytojas Lietuvos istorijos institutas). 
Naujieji metai - vienintelè šventè, buvusi nedarbo diena tarpukario Lietuvoje (ir Lenkijos okupuotoje Lietuvos dalyje), sovietinejje Lietuvoje ir atstačius nepriklausomą Lietuvos valstybę. Šią dieną nedirba ir Lenkijoje bei Rusijoje gyvenantys žmonès. Sovietų Sąjungoje tik ši šventė nepasižymèjo aiškia ideologija $[18,53]$ ir turèjo daugiau pasaulietinę negu religinę prasmę. Liberto Klimkos teigimu, ji neturèjo ir savitų gamtos virsmų padiktuotų apeigų $[10,24]$. Nagrinejjant Naujųjų metų papročius galima pažymėti, kad ši šventè tarsi atkartoja Kūčių ir Kalèdų ritualus, o žvelgiant ị lietuvių ir daugelio kitų krikščioniškų tautų ritualinius metus matyti, kad Naujieji metai yra nuo Kalèdų iki Trijų Karalių trunkančio tarpušvenčio laikotarpio centre. Tai ypatingas laikas, žymintis ribą tarp senųjų ir naujųjų metų, tad net praeito šimtmečio pradžioje vilniečiai stengdavosi sunkiai nedirbti. Greta Vilniaus esančiuose kaimuose kai kurie darbai šiuo laiku iš viso buvo draudžiami, o vakarus vadino šventais $[31,145]$. Kita vertus, kiek kitaip negu katalikų, stačiatikių ir sentikių bažnytiniai metai remiasi Julijaus kalendoriumi ir nuo oficialaus Grigaliaus skiriasi 13 dienų. Tai lemia ir kai kurių šias religijas išpažistančių žmonių skirtingą švenčių laiką $[14,52-60]$.

Straipsnyje, remdamiesi stebejjimo, lyginamuoju ir interpretaciniu tyrimo metodais, išsikeliame tikslą - atskleisti Naujųjų metų šventès etninius ir kultūrinius savitumus. Šiam tikslui palyginsime lietuvių, lenkų ir rusų švenčiamos šventès dalyvių sudètį, šventimo vietą, šventines vaišes, šeimoje palaikomas naujametines tradicijas, ateities spejjimus ir šventès vietą ritualinių metų struktūroje.

Pagrindinis straipsnio šaltinis - pagal etnografinių klausimų lapą „Šiuolaikinès vilniečių šventės šeimoje: Pirmoji dalis“ Lietuvos edukologijos universiteto studentų 2012 ir 2013 metais sukaupta medžiaga. Apklausti 175 respondentai, tarp jų 83 lietuviai, 65 lenkai, 23 rusai, 3 ukrainiečiai ir 1 baltarusis. Pagal tikybą daugiausia katalikų - 84 proc. (lietuviai ir lenkai bei dalis rusų - 5 respondentai), taip pat apklausta 10 proc. stačiatikių ir 3 proc. sentikių (rusai, ukrainiečiai, baltarusiai). Keli respondentai save priskyrè senajai baltų religijai ar teigè esantys netikintys. Pagal amžių 3 proc. respondentų yra gimę 1964-1970, 36 proc. - 1971-1980, 44 proc. - 1981-1990 ir 27 proc. - 1991-1994 metais. Taigi daugumos pateikejų amžius - nuo 20 iki 40 metų. Taip pat naudotasi ir trijų Vilniaus miesto gimazijų (lietuvių, lenkų ir rusų mokomąja kalba) moksleivių 2013 m. anketavimo būdu sukaupta medžiaga (atitinkamai po 23, 21 ir 21 anketas); buvo apklausti vienuoliktos klasès (17-18 metų) mokiniai. Pateikejjų buvo prašoma papasakoti apie 2012 ar 2013-ųjų sutikimą (2).

\section{ŠVENTĖS IŠTAKOS}

Etnologinių Naujiesiems metams skirtų tyrimų Lietuvoje nèra gausu. Pirmasis duomenis apie liaudiškus Naujųjų metų papročius paskelbẻ Liudvikas Adomas Jucevičius 1842 m. publikuotuose „Žemaičių žemės prisiminimuose“. Čia minima, kad „Naujieji metai liaudyje, kaip ir aukštesniojoje klasẻje, yra sveikinimų ir linkejjimų diena - ne dèl etiketo (nes to nežino), bet nuoširdžių linkèjimų“. Autorius pateikia ir septynis naujametinius spejjimus [9, 453-454] (3). Pasak XIX a. pabaigos ir XX a. pradžios situaciją apibūdinusio Juozo Kudirkos, iki Pirmojo pasaulinio karo per Naujuosius metus visur, išskyrus Suvalkiją, buvo kartojama Kūčių vakarienè, tačiau nusistovejjusių Naujųjų metų sutikimo papročių, išskyrus

(2) Lauko tyrimų duomenys saugomi Lietuvos istorijos instituto Etnologijos skyriuje.

(3) Žemaitijos regione naujametiniai vedybiniai spejimai gana plačiai gyvavo ir XX a. pirmojoje pusèje $[15,96-112]$. 
Aukštaitiją, nebuvo [11, 243-248]. O jaunimo pasilinksminimai tarpukariu per Naujuosius metus vyko visur, rečiau - tik Vakarų Lietuvoje [22, 42].

$\mathrm{XX}$ a. pradžios miesto Užgavėnes nagrinèjusi Lina Petrošienė pažymėjo, kad miesto šventė forma, turiniu ir atliekamomis funkcijomis skyrèsi nuo kaimo švenčių [17, 21]. Panašią situaciją galima įžvelgti ir nagrinejjant Naujuosius metus Vilniuje. XX a. pradžios papročius apibūdinusios Laimos Laučkaitès duomenimis, per Naujųjų metų sutikimą rautai su šokiais buvo rengiami generalgubernatoriaus rūmuose. Pagrindinèse miesto salèse - Polesès valdybos geležinkelio klube, Miesto saleje, Šv. Jurgio viešbutyje, privačiose rezidencijose - vyko teminiai kaukių baliai, maskaradai [12,473]. Vilniečiai šią šventę šventė ir šeimose.

Maria Znamierowska-Prüfferowa, pabandžiusi apibūdinti XX a. 5-ojo dešimtmečio Vilniaus kultūrą, Naujųjų metų išvakares įvardijo kaip Silvestro vakarą, o šią dieną vadina „riebiosiomis Kūčiomis“. Pasak lenkų katalikų papročius apibendrinusios etnologès, per Naujuosius metus žmonès antrą kartą laužia kalèdaičius, „kai kurie vèl verda kisieliuką su medumi, grūda aguonpienị", tačiau tądien jau kepa ir riebius blynelius, valgo dešrą su virtais ar žaliais kopūstais, „meldžia Dievo palaimos ir sutinka Naujuosius metus“. Ryte „dalijami linkejjimai ir spejjamas vasaros oras. Manoma, kad jeigu tą dieną šaltis, vasara bus karšta“ [31, 145-146]. Apibūdindama stačiatikių papročius ji pamini, kad iš aplinkinių kaimų kilę baltarusiai ir rusai tos dienos išvakarèse „buria būsimąsias vedybas. Skaičiuoja tvoros mietus ir kviečių grūdus" $[31,214]$ (4). Ausburgo evangelikai laikèsi vokiškų papročių. Naujųjų metų išvakarèse jie tiekdavo liesą vakarienę, „vèl degdavo eglutė, žmonès valgydavo spurgas, Berlinerpfannkuchen, o vidurnaktị sutikdavo Naujuosius metus gerdami karštą Glühwein - raudonąji vyną, virtą su prieskoniais“ [31, 221-222]. Etnologès many$\mathrm{mu}$, Vilnius turi senas tradicijas, neatskiriamai susijusias su kaimu, tačiau turinčias bendrų bruožų, būdingų ir „didesniems Europos plotams“ [31, 137]. Taigi mieste funkcionavo ir „kaimiška kultūra“, fiksuota daugelyje Dzūkijos ir Aukštaitijos kaimų.

Sovietmečiu masinėmis informacijos priemonėmis visaip buvo skatinamas Naujųų metų šventimas. Vaidybiniai filmai „Karnavalo naktis“, „Likimo ironija, arba po pirties“, gausiai leidžiami naujametiniai atvirukai, šventinė televizijos programa ir Kremliaus kurantų dūžiai skatino pamiršti Kūčias ir Kaledas ir formavo Naujųjų metų kaip ribinès, Arnoldo Van Gennepo žodžiais, „perejimo“ simboliką [28, 178-179] įkūnijančios, šventès stereotipus. Dalia Senvaitytė pažymi, kad ypač daug dėmesio to meto ideologijoje ir atitinkamai spaudoje buvo skiriama naujametei šventei vaikams populiarinti [19, 114-115]. Multiplikaciniai filmai vaikams, Senelio Šalčio dovanèlès, šventinės eglutès turèjo užtikrinti ir šios šventès ateitị. Ir iš dalies tai pavyko.

1998 ir 1999 metais Dzūkijoje ir Aukštaitijoje atliktų tyrimų duomenimis, 1969-1978 m. gimę respondentai ị vakarèlius dažniausiai susiburdavo per Naujuosius metus [21, 172]. Kaip linksmiausią ir laukiamiausią šventę Naujuosius metus tyrimo metu ịvardijo dauguma 15-20 ir 21-30 metų amžiaus respondentų [21, 170]. XXI a. pradžioje Lietuvos kaimų ir mažųų miestelių (tirta 150 vietovių) jaunimas rengè Naujųjų metų vakarèlius ịvairiuose etnografiniuose regionuose - nuo 80 iki 96 proc. tirtų vietovių. Dažniau susiburiama tik per Jonines [24, 101]. Tačiau pastaruoju metu padètis pakito: atgavus nepriklausomybę vèl sureikšminamas Kalẻdų šventimas, o sovietmečiu ị Naujuosius metus perkelta ribinės metų

(4) Matyt, vedybinè ateitis spejjama pagal merginų apkabinamą tvoros mietų ar pasemtą grūdų skaičių: jei porinis - tikèta, kad tais metais ištekès. Šis spèjimas, plačiai paplitęs tarp lietuvių katalikų, pasiekẻ ir šias dienas. 
šventès simbolika vèl grąžinama Kalėdoms. Tai paliudijo absoliuti dauguma šio tyrimo respondentų, Kalèdas įvardijusių kaip svarbiausią metų šventę.

XX a. antroji pusè ir XXI a. pradžia atnešè radikalių socialinių ir ekonominių pokyčių Lietuvos ir didžiausio jos miesto Vilniaus gyventojų kultūrai. Kokie jie, pabandysime atsakyti Naujųjų metų kaip „miestietiškos“, „universalios“ bei ịvairiose istorinèse epochose pripažįstamos šventès tyrimu.

\section{ŠVENTĖS DALYVIAI IR VIETA}

Jacqueline Simson ir Steve’as Roadas pažymèjo, kad Naujieji metai Anglijoje prarado beveik visus tradicinius papročius ir tikejjimus. Daugelis žmonių šią šventę sutinka ramiai namuose arba eina ị vakarèli, kuris, be naujametinių giesmių, mažai kuo skiriasi nuo kitų pobūvių [20, 256-259]. Kyla klausimas, kuo ši šventè yra išskirtinė šiuolaikinėje vilniečių šeimoje? Nors ši šventė yra vieša, vis dèlto didesnė dalis respondentų teigè, kad ji švenčiama ne tik su draugais, bet ir su šeimos nariais. Nesukūrę šeimos ją švenčia dažniau su draugais, tačiau

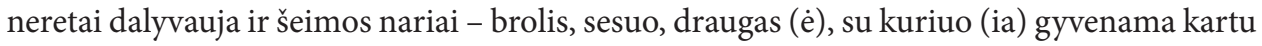
oficialiai nesusituokus ar tik numatoma kurti šeimą.

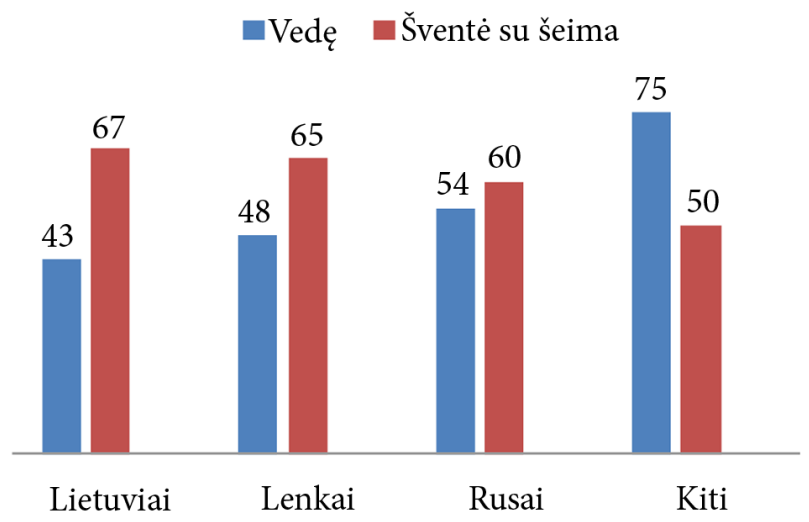

1 pav. Vedusiujų / gyvenančių kartu ir šventusių Naujuosius metus šeimoje (proc.; N = 175)

Pirmame paveiksle matome, kad dalis nesusituokusių žmonių šventė kartu su šeima. Kita vertus, ir šeimą sukūrę respondentai ne visada turejjo galimybę Naujuosius metus sutikti su šeimos nariais - kai kuriems iš jų teko dirbti. Kartais Naujuosius metus sutinka tik draugaujančios poros ar sutuoktinių šeima, brolis ir sesuo, o kiti šeimos nariai švenčia atskirai. Kai kada Naujuosius metus atšvęsti spejjama keliose vietose: pavyzdžiui, namuose ir pas močiutę, namie ir pas tèvo seserị ar iki vidurnakčio švenčiama su draugais, o gerokai po dvylikos sugrị̌tama ị šeimos ratą. Fiksuotas atvejis, kai ir tèvai, ir draugų kompanija švenčia viename name, bet atskirai prie atskirų stalų.

Jei skirtingų tautybių jaunimo duomenys gana panašūs, tai moksleivių jie kiek skiriasi. Apie pusę mokyklos rusų mokomąja kalba moksleivių Naujuosius metus sutinka su šeima, o tarp lenkų ir lietuvių moksleivių aiškiai vyrauja paprotys šią šventę sutikti su draugais. Neretai ì šeimos švenčiamą naujametinę šventę ateina ir draugų. Su draugais šią šventę švenčia maždaug du trečdaliai pateikejjų. 


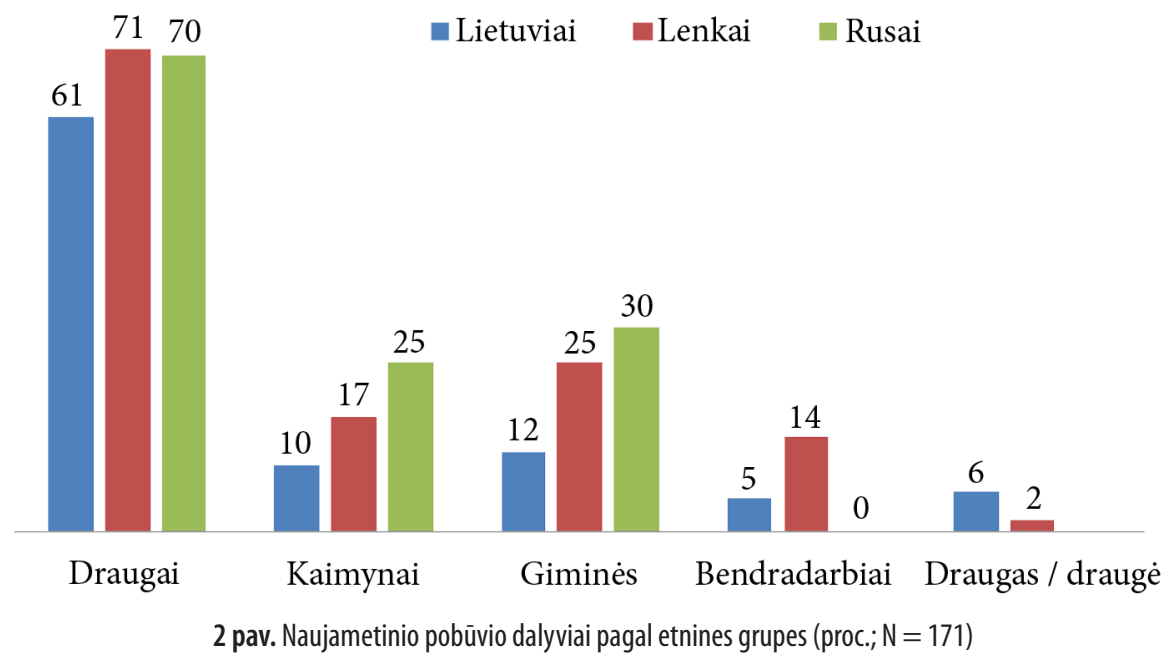

Kaip matome iš 2 paveikslo, ị lietuvių šventes giminès ateidavo rečiausiai, panašus požiūris ir ị kaimynystę. Lenkai ị svečius neretai kviečia ir bendradarbius.

Šventès analizei svarbi ir jos šventimo vieta. Rusai dažniau Naujuosius metus linkę sutikti namie, o lietuviai ir lenkai - pas draugus ar viešosiose erdvėse: kavinèje, sodyboje, miesto centre (vyrauja Naujųjų metų sutikimas Katedros aikštejje), kituose miestuose ir kaimuose, miške ar užsienio šalyje (3 pav.).

Naujujų metų sutikimo vieta

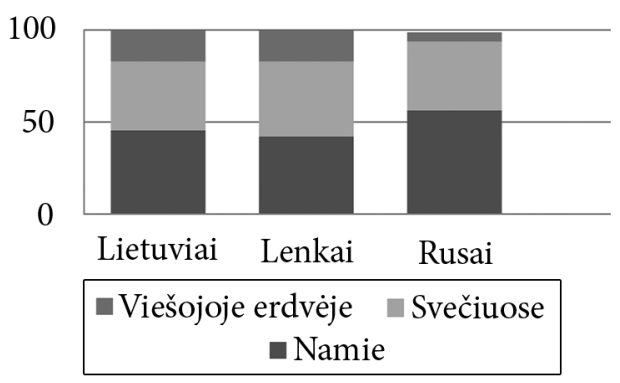

3 pav. Naujujų metų sutikimo vieta pagal etnines grupes (proc.; $\mathrm{N}=171$ )

Analizuojant Naujųjų metų vidurnakčio sutikimo vietą, matyti, kad patalpoje vidurnaktị dažniausiai sutinka rusai (4 pav.). Lietuviai ir lenkai dažniausiai vidurnaktị sutinka lauke, šaudami fejerverkus, šampaną, sveikindami vieni kitus. Švenčiant gamtoje kartais kuriamas laužas. I bažnyčią per Naujuosius metus einama retai. Artimieji ir draugai dažniausiai pasveikinami telefonu (skambinant ar pasveikinant žinute), rečiau - elektroniniu paštu. Paštu siunčiami sveikinimai jau nyksta, plinta sveikinimai „Facebook'e“ ir per „Skype’ą“.

Analizuodami pirmosios Naujųjų metų dienos sutikimą, etninès specifikos negalime išskirti. Visų etninių grupių atstovai, šventę gimtajame mieste, pirmąją Naujųjų metų dieną dažniausiai sutinka namuose, žiūrẻdami šventinę televizijos programą, rečiau - pas 
Naujujų metų vidurnakčio sutikimo vieta

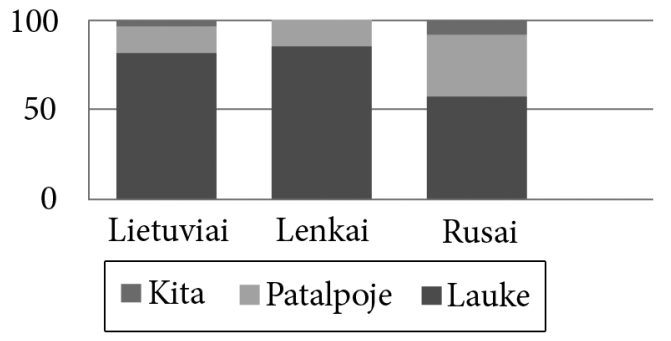

4 pav. Naujujų metų vidurnakčio sutikimo vieta pagal etnines grupes (proc.; $N=171$ )

draugus. Neretai tą dieną pabuvoja keliose vietose. Kai kada eina ị renginị mieste, kavinę, barą, teatrą, bažnyčią, lanko tèvus, senelius, brolị, seserị, gimines; dalis respondentų apskritai tos dienos nešvenčia, tik „iprastai praleidžia dieną“. Susidaro îspūdis, kad sureikšminamos šventès išvakarès (kaip ir Kalèdų, Joninių), o tikroji šventinė diena skiriama „poilsiui nuo šventimo“. Tą paliudija respondentų žodžiai: „ilsẻjimuisi namie“, „visą dieną miegojau“. Pasak vienos respondentès, „Pirmąją Naujụjų metų dieną miegojau iki pietų, vèliau važiavau namo ir išgèriau šampano su tėvais, sese, jos draugu. Vèliau žiūrejjome šventines laidas“, kitos teigimu, „Naujųjų metų dieną paprastai nešvenčiu. Dažniausiai išsimiegu ir po pietų susitvarkau namus“. Ukrainietès teigimu, tą dieną žiūrima filmus ir niekur iš namų neinama. Sausio pirmosios specifiką apibūdinusios rusès teigimu: „nešvenčiama ypatingai, pabaigiame valgius ir gèrimus, žiūrime filmus.... "Sausio antroji yra darbo diena, todèl nèra galimybės ilgiau švęsti ar vykti kur nors toliau nuo namų. Dèl tobulejjančių ryšio priemonių pasidalyti naujametiniais ịspūdžiais ir linkejjimais galima ir tiesiai iš namų.

\section{ŠVENTINIS STALAS}

Svarbus šventės akcentas - šventinis stalas. Didesnes ar mažesnes vaišes aptiksime kiekvienos šventès ritualinèje struktūroje $[27,163]$, tačiau Naujųjų metų valgiai plačiau nebuvo tyrinèti. Vieninteleje stambesnejje ritualinių metų kulinarijos studijoje ši šventė net nebuvo išskirta [13], todèl nagrinèti naujametinị stalą iš laiko perspektyvos gana keblu. Tai paskatina skirti daugiau dèmesio dabarčiai.

Analizuojant šventinius patiekalus nematyti didesnių etninių skirtumų. Daugelis šeimų laikosi tik joms būdingų tradicijų, patiekiami šeimos narių mègstami patiekalai. Tam tikrų skirtumų galima įžvelgti tik išskyrus atskiras produktų grupes (5).

Visų tautybių respondentai daugiausia išskyrė alkoholinių ir gaiviųjų gèrimų grupę (5 pav.). Gèrimų hierarchinèje struktūroje tarp visų tautybių vilniečių vyrauja šampanas (šampanizuotas vynas) - pagrindinis šių dienų produktas, simbolizuojantis Naujųjų metų šventę. Lenkų tautybès respondentai išskyrè ir mésos produktus, o rusai ir lietuviai jiems teikẻ mažesnę reikšmę. Lenkų vaišèse vyrauja paukštienos patiekalai, lietuviams santykinai būdingesni naminių gyvulių mèsiški patiekalai. Kiek kitaip negu per Kūčias, ant naujametinio

(5) Produktų grupès atskleidžia tik sąlyginį vienos ar kitos rūšies patiekalų pasiskirstymą. Dažnai respondentų pateiktas patiekalo apibūdinimas nèra detalus, o ir atskiras valgis neretai apima kelias patiekalų grupes. Jos išskirtos pagal vyraujantị produktą, pavyzdžiui, mišrainès priskiriamos prie daržovių patiekalų, pyragèliai, nepaisant jų įdaro, - prie duonos ir grūdų, taip pat nesigilinant ị jų sudètị išskirtos atskiros gèrimų ir saldumynų grupès. Prie žuvų patiekalų priskiriami ir jūros gyvūnų produktai. 


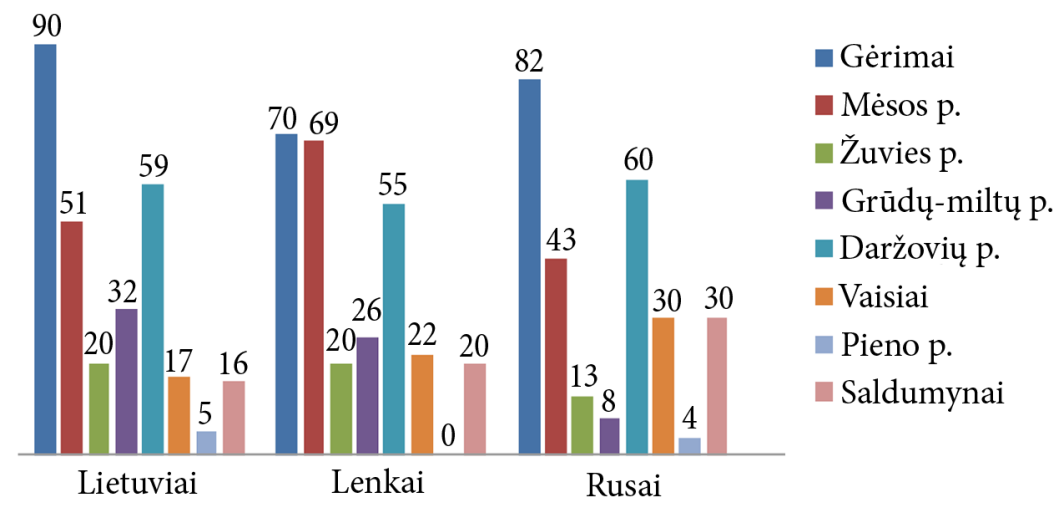

5 pav. Naujujų metų šventinis stalas pagal produkto rǔš ir etnines grupes (proc.; $\mathrm{N}=171$ )

stalo nèra daug žuvies ir jūros gyvūnų patiekalų. Juos dažniau paminèjo lietuviai ir lenkai. Iš žuvies patiekalų išsiskiria silkè. Lietuviai nedaug lenkia lenkus grūdų patiekalų gausa, dažniausiai minimi sumuštiniai. Visos trys etninès grupės dažnai rinkosi daržoves, tik rusai ir lietuviai išskyrė mišraines (lietuviai - ypač baltą mišrainę), lenkai - salotas. Kiek rečiau minimi bulvių patiekalai (keptos, virtos bulvès, košè, traškučiai). Rusai itin sureikšmino vaisius. Jie ir ukrainiečiai paminejjo mandarinus. Nustebino ir tai, kad respondentai labai retai (išskyrus rusus) minėjo saldumynus, iš jų dažniausiai vyravo tortai (bananinis, medaus, skruzdèlynas, vaflinis). Beveik neminimi pieno produktai, grybai, sriubos.

Tik kelių respondentų nuomone, stalas buvo panašus ị kalèdinị. Pasak lenkès, nebuvo tik kisieliaus ir kūčiukų, o rusès teigimu, be tradicinių Kalèdų patiekalų, dar buvo specialiai keptas vaflinis tortas. Specifinių, tik šiai šventei pagamintų patiekalų ívardyta labai nedaug. Pasak lenkès, specialiai šiai progai kepa antị (vienu atveju - su obuoliais). Keptą antị, kaip specifinį naujametinị patiekalą, minejo ir lietuvè. Dvi lietuvių ir viena lenkų šeimos šiai dienai kepa kalakutą. Rusè ịvardijo specialiai tai progai ypatingu būdu kepamą mėsą, lenkè išskyrẻ šiai progai iškeptą medaus tortą.

Taigi nèra specifinių, vienai ar kitai etninei grupei būdingų patiekalų. Daugelis maisto produktų negali būti siejami ir su ilgalaike tradicija ar etnokulinariniu paveldu. Turime pritarti Johnui Tomlinsonui, kad globalizacija susilpnina materialų maisto kilmès ir vartojimo vietos ryši $[26,131]$.

\section{TRADICIJOS SUVOKIMAS}

R. Paukštytės-Šaknienès tyrimai atskleidė gana konservatyvų Vilniaus miesto jaunimo požiūrị i beveik nekintančią ir iš kartos ị kartą perduodamą tradiciją [16, 206-217]. Vis dèlto laiką, per kuri gali susiformuoti tradicija, ne tik jaunimas, bet ir patys etnologai supranta gana ịvairiai. Antai Švedijos folkloristė Marlene Hugoson, analizuodama Velykų medžio paplitimą per devynerius metus, vartoja „dabarties tradicijos“ (instant tradition) sąvoką $[8,75-86]$.

Kaip jau minèjome, beveik visi respondentai ateinančius metus pažymi šampano šūviu, sveikina kitus šventès dalyvius, didesnè dalis šauna fejerverkus (ar žiūri, kaip tai daro kiti). Retai šia proga einama ị bažnyčią, ne visi švenčiantys sodyboje ir turèdami tam sąlygas kuria laužą. Atsakiusieji ị klausimą, kokių dar Jūsų šeima laikosi Naujųjų metų sutikimo tradicijų, pagal tautybę pasiskirsto maždaug po lygiai. 


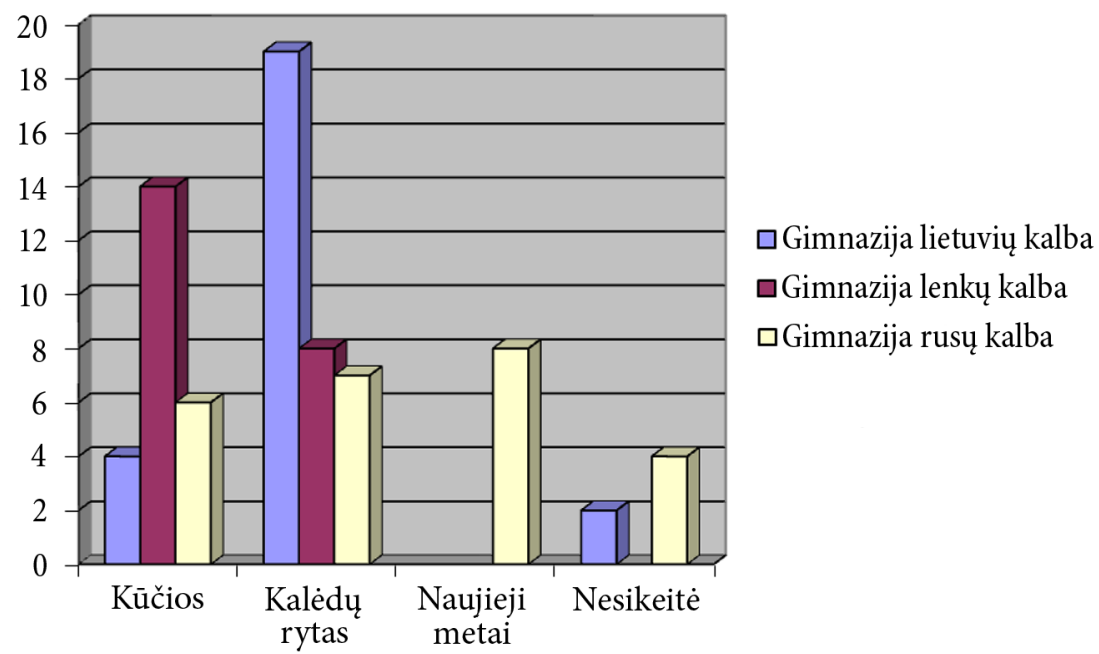

6 pav. Metų pabaigos dovanos moksleivių apklausos duomenimis $(\mathrm{N}=65)^{*}$ * Kai kurie pateikejai nurodè kelias dovanų teikimo progas.

Pasak ukrainietès, kai ji buvo maža, ta proga kviesdavo Senị Šaltị, jam turèjo sakyti eilèraščius. Kitos jos tautietės teigimu, žiūrimi seni filmai su tèvais, nes tai jų jaunystès nostalgija.

Pasak rusų, gyvuoja tradicija prieš Naujuosius metus atiduoti skolas, atsiprašyti artimųjų už skriaudas. Per Naujuosius metus priimta rengtis kuo ryškesnėmis spalvomis, lankomi kaimynai ir vaišinami ar paprasčiausiai linksminamasi, žiūrimi filmai. Viena respondente teige, kad Naujuosius metus švenčia kartu visa šeima, niekada nebūna atskirai nuo savo šeimos. Taip pat gyvuoja tradicija tarp šeimos narių keistis dovanomis. Keitimąsi dovanomis kaip specifinị rusams būdingą bruožą patvirtina ir moksleivių apklausa.

Kita vertus, tradiciją per Naujuosius metus keistis dovanomis mini ir vyresnieji lenkai. Pasak jų, šia proga teikiamos dovanos, visi sveikinami, važiuoja pas gimines, aplankomi artimieji, sutvarkomi namai, ruošiamas stalas ir laukiama svečių. Pasiruošimą šventei ịprasmina ir šeimos narių ejjimas ị pirtị. Kaip šeimos tradicija nurodoma ir naujametinès televizijos programos žiūrèjimas ar per „rusų“ Naujuosius metus skambinimas giminėms ị Maskvą. Kai kada ir lenkų šeimose per rusų Naujuosius metus taip pat šaunamas šampanas (6). Kai kurie tradicija ịvardijo Naujųjų metų sutikimą su tais pačiais draugais. Keliose lenkų šeimose stengiamasi turèti tų metų simboli pagal kinų kalendorių, pavyzdžiui, pateikèja sutiko Naujuosius metus su raudonu megztiniu, kuris simbolizavo drakono metus. Kartais tų metų simbolis pastatomas ant stalo. Minima ir tradicija palydèti senus metus - tai daroma 23 valandą susėdus prie stalo. Kai kada sutikus Naujuosius metus einama svečiuotis pas kaimynus. Pirmą Naujụjų metų dieną orkaitejje kepami kepsniai arba naujametinis pyragas. Svarbūs ir drabužiai. Verta „turèti ar dèvėti ką nors naujo“. Kaip ir rusų šeimose, sutinkant Naujuosius metus linkima gèrio ir atsiprašoma už blogą. Minima ir tradicija kieme lipdyti sniego senį.

Lietuviai minejjo, kad tą dieną daug šoka, dainuoja, degina šaltas ugneles, visi nusifotografuoja, mama daro sausainukus su obuoliais, šeima klausosi astrologinių prognozių

(6) Šeškinès mikrorajone šaunami fejerverkai, bet ne taip intensyviai, kaip per Lietuvos laiku švenčiamus Naujuosius metus. 
ar šeimos nariams pasisako apie asmeninius kitų metų planus, net sudaromas jų sąrašas. Kartais einama čiuožinèti ant ledo, maudytis pirtyje ar minima tradicija „būti nusipraususiems". Kiti eina į teatrą, koncertą filharmonijoje ar patys dainuoja lietuvių liaudies dainas, šoka lietuvių liaudies šokius, dovanoja dovanas, žaidžia „Monopolị“. Tradicija gali būti buvimas kartu per Naujuosius metus ar su draugais. Kai kada, anot respondentų, tradicijų laikosi tik tèvai - eina ị bažnyčią.

Taigi įvairių etninių grupių atstovų šeimos tradicijos samprata panaši. Tradicija gali būti kelių kartų žinomas (kartais iš Kūčių ir Kalèdų pasiskolintas), kartais modifikuotas ar palyginti naujai (dažniausiai internete) „atrastas“ paprotys, jaunosios kartos atstovų mintyse jau igijęs ilgalaikès ir nekintančios vertybès stereotipą. Kai kada tradicijos tapatinamos su tikejjimais.

\section{NAUJUৃJŲ METŲ TIKĖJIMAI}

Jau minejjome, kad pirmieji liaudies švęstų Naujųjų metų paminèjimai susiję su ateities spèjimais. Kaip pažymèjo Juozas Kudirka, kai kuriose Rytų Lietuvos vietovėse prieš Naujuosius metus spejjama dažniau negu prieš Kalèdas $[11,249]$. Todèl logiška, kad Naujųjų metų spèjimai galejjo išlikti ir šios Lietuvos dalies mieste, kur anksčiau negu kaimo kultūroje ì gyventojų buitị atejo laikrodis ir Naujųjų metų ribą žymėjo ne ištęstas dvylikos dienų laikotarpis, o konkreti parų sandūrą žyminti 24 valanda.

I klausimą, „Kokių žinote Naujųjų metų spejjimų“, didelè dalis respondentų teigè, kad jokių spejjimų nežino. Pavyzdžiui, baltarusè nuoširdžiai atsakè: „niekada nežinojau, kad tokių yra“, tačiau dalis jų nurodè tam tikrus spejjimus. Pasak Pranès Dundulienès, per Naujuosius metus, kaip ir Kalèdas, didelè reikšmè buvo skiriama magiškai „pirmosios dienos" idèjai. Kaip elgsiesi pirmą dieną, toks būsi visus metus [4, 35-39]. Naujametinis tikejjimas, kad kaip sutiksi Naujuosius metus, taip juos ir praleisi (7), ir šiomis dienomis dažniausiai minimas visų etninių grupių atstovų. Ivairų tautybių respondentai taip pat sureikšmina naujametinę nuotaiką, žmones, su kuriais sutinka Naujuosius metus, pinigu turèjimą, naujametinius drabužius, suvalgyto maisto gausą. Panašūs tikejjimai per Naujuosius metus gyvavo ir tradiciniame Lietuvos kaime [1, 43-49]. Kita tikẻjimų grupé tradicinius Naujųjų metų papročius susieja su Kūčiomis. Lietuvių ir lenkų teigimu, kaip ir prieš Kaledas, prieš Naujuosius metus reikia grąžinti skolas, susitaikyti, nesipykti ar juos sutikti švariems, atidavusiems visas skolas ir bažnyčioje išpažinus nuodėmes. Rusai šias reikšmes traktavo kaip šeimos tradiciją.

Labai svarbus ir Naujųjų metų vidurnaktis. Visų etninių grupių atstovai pateikè naujametinių būrimų. Šiuo atveju dažnai atliekami ir su tradicija mažai besisiejantys veiksmai. Teigiama, kad išsipildys vidurnaktị sugalvotas noras. Kai kuriais atvejais dar reikia atlikti papildomų veiksmų, pavyzdžiui, prieš tai suvalgyti vynuogę arba sudeginti lapeli su užrašytu noru, pelenus supilti ị šampaną ir vidurnaktị išgerti. Kartais užtenka norą parašyti ant popieriaus ir prieš miegą pakišti po pagalve tikint, kad jis išsipildys.

2005-2008 metų papročių tyrimais nustatyta, kad vilniečių jaunimo naujametiniai vedybų spejimai labai reti [23, 100-109]. Šio tyrimo metu tokie spejjimai jau nebefiksuoti, tačiau spejjama apie poros meilę. Tą galima padaryti kartu nemačiomis išgeriant gèrimo ir pagal jo stiprumą pasakyti apie tos poros meilę. Analogijų neturi ir spejjimas, kai po viena iš kelių lèkščių padedama moneta: atspejjus manoma, kad tais metais pinigų nepritrūks.

(7) Galima versija: „kaip palydèsi senus metus, tokie bus ir nauji metai“. 
Tradiciškai per Naujuosius metus buvo spejjami orai $[1,43-44 ; 30,13]$, tačiau mūsų tyrimų duomenimis, apie tai užsiminè tik du žmonès. Tai rodo, kad šiuolaikiniam miesto žmogui ši sritis jau nebesvarbi.

Naujametiniai spejimai atliekami ir išèjus ị kiemą. Tikima, kad jei pirmas sutiktasis yra vyras, metai bus geri, sutikus moterị metai bus prastesni. Laimę neša ir gyvūnai: per Naujuosius Metus ị laiptinę ịleidžiama katè, kad metai būtų sẻkmingi (8). Pasak 1990 m. gimusios merginos, dauguma Naujųjų metų spejjimų panašūs ị Kūčių. Kadangi Naujuosius metus ji šventè kaime, pabandè tokį: triskart apibègo apie trobą ir po trečio rato pamatytas vaizdas parodè, kokia bus ateitis (9). Apibendrinant naujametinių tikèjimų sriti galime teigti, kad įvairių tautybių žmonės Naujųjų metų spẻjimams tebeteikia išskirtinę reikšmę. Kita vertus, sunku numanyti, kiek jais tikima.

\section{ŠVENTĖ RITUALINIŲ METŲ STRUKTŪROJE}

Vilniečių ritualinių metų struktūroje Naujieji metai patys svarbiausi po Kalèdų (su Kūčiomis) ir Velykų. 15 iš 175 pateikejjų svarbiausia metų švente ịvardijo Naujuosius metus (10), tarp jų penki lenkai (8 proc.), po keturis lietuvius (5 proc.) ir rusus (17 proc.), po vieną baltarusị (100 proc.) ir ukrainietị (33 proc.). Analizuojant Naujųjų metų išskyrimo priežastis nurodyti keli motyvai, vienas iš juc - pramoginis. Trijų lenkių, ukrainietès (ji minejjo ir gimtadienị) ir lietuvio teigimu - tai tiesiog linksmiausia šventè. Išskiriami ir kiti du motyvai - Naujieji metai suvokiama kaip ribiné, perejjimo apeigų simboliką ịūnijusi ir šeimą suburianti šventè. Pasak lenkès: „Išskirtine švente ịvardyčiau Naujuosius metus. Jaučiamas tarsi peržengimas iš vienos erdvès ị kitą. Apmąstai su šeima praejjusius metus,

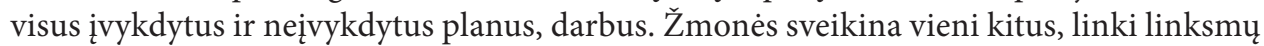
Naujųjų metų. Žmonès ruošiasi, baigia visus pradètus darbus, kad Naujieji metai būtų ramūs, praeitų ne veltui. Labai patinka šventinẻ nuotaika vidurnaktį: fejerverkai, šampano taurès, sveikinimai“. Jos tautietès manymu, Naujieji metai svarbūs tuo, kad prasideda naujas etapas gyvenime. Naujuosius metus ir gimtadienį išskyrusios lietuvès teigimu, ši šventẻ laukiama todèl, kad atvažiuoja giminès iš užsienio, rusè Kalèdas ir Naujuosius metus išskiria motyvuodama, kad jų metu susirenka daugiausia artimųjų. Kita jos tautietė pabrèžè pasiruošimą šiai šventei, papuoštus namus, suejusius šeimos narius, pridurdama, kad tai - stebuklų metas. Pasak jos tautiečių, išskyrusių Velykas ir Naujuosius metus bei Kaledas ir Naujuosius metus, tai - šeimyninès šventès. Baltarusės teigimu, „Naujieji metai švenčiami visa šeima, stengiamès, kad visiems būtų gera", nes sakoma, kad kaip Naujuosius metus sutiksi, taip juos ir praleisi. Kad kiti metai būtų dosnūs, stengiamasi paruošti daug valgių ir dovanų. Taigi daliai respondentų Naujieji metai - šeimos šventè. Kita vertus, kartais ji net nepripažistama švente: viena lenkẻ teigé, kad „Mums tai nèra šventè, tik diena, kai galime su šeima pabūti kartu“ (160). Nors šių dienų etnologai pažymi šeimos krizę, šeiminị gyvenimą ịvardija kaip nešiuolaikišką ir neatitinkantị vis spartẻjančio gyvenimo ritmo [6, 153-157], daliai žmonių galimybė pabūti drauge su artimaisiais yra labai svarbi. Kita vertus, daugelis šiuolaikinių naujametinių aprašų verčia prisiminti Kūčias. Sovietmečiu kovojant su religingumu, dalis Kūčių papročių tapo laisvai švenčiamų Naujųjų metų dalimi. Be to, sentikių ir stačiatikių religijas išpažǐstantys

(8) Etnografiniai šaltiniai iš Panevěžio apskrities liudija, kad 12 valandą juodą katę nešdavo ị kryžkelę ir pagal jos bẻgimo kryptị sužinodavo, iš kurios pusès atvyks mylimasis ar mylimoji [5, 349].

(9) Panašūs naujametiniai spejimai užrašyti Tveruose ir Skaudvilëje $[15,109,111]$.

(10) Iš jų trys greta šios šventès nurodè gimtadienį, Kalèdas ar Velykas. 
žmonės taip nesureikšmina Kūčių, kaip katalikų tikejjimą išpažistantys lietuviai ir lenkai. Tai ir paaiškina, kodèl šią šventę išskiria tokia didelè dalis klausinètų rusų, ukrainiečių ir vienintelè baltarusè.

Rusai švenčia ir „Senuosius Naujuosius metus“. Jau moksleivių apklausa rodo, kad 40 proc. rusų ir 10 proc. lenkų (11) kalbomis besimokančių vilniečių Naujuosius metus švenčia ir sausio pirmąją, ir sausio keturioliktąją, 5 proc. mokyklos rusų kalba moksleivių minejjo tik „rusiškus“ Naujuosius metus. Vyresni, 20-40 metų, rusai Naujuosius metus dažnai šventė pagal abu kalendorius, tačiau Senieji Naujieji metai paminimi kukliau, nes šią dieną būdavo dirbama. Naujieji metai sausio pirmąją dažnai sutinkami kelis kartus - pagal Lietuvos ir Maskvos laiką, tačiau etninė šventès ar ją sudarančio ritualo, papročio specifika pačių žmonių nèra sureikšminama.

\section{IŠVADOS}

Naujųjų metų chronologinis artumas Kalėdoms apeiginių metų struktūroje ir išskirtinis šiai šventei teikiamas dèmesys istorijos perspektyvoje suformavo šios šventès tradicijas šeimoje. Sovietmečiu suformuoti Naujųjų metų kaip išskirtinès, ribinę, perẻjimo apeigų simboliką ¡ikūnijusios šventès stereotipai gyvi ir šiandien.

Tyrimas atskleidè, kad net ir pasaulietinei šventei tam tikrą (nors ir netiesioginị) poveikį turi religija. Lygindami lietuvių, lenkų ir rusų papročius, matome rusų tautybès žmonių Naujiesiems metams teikiamą didesnę svarbą. Sentikių ir stačiatikių šeimose mažiau reikšmingos negu katalikams Kalèdų išvakarès, todèl Naujieji metai dažnai jaunimui tampa svarbiausia šeimos švente. Nepaisant rusų švenčiamų Senųjų Naujųjų metų ar Naujųjų metų sutikimo Maskvos laiku, šios šventès etninė specifika pačių žmonių nėra aiškiai išreikšta ir sureikšminama. Lietuvoje, Lenkijoje ir Rusijoje funkcionuojanti krikščioniška kultūra ir panaši ritualinių metų struktūra neleidžia pasireikšti ryškiems skirtumams, kokius galètume rasti lygindami totorių, karaimų ar žydų šventes.

Išanalizavę kelių tautybių vilniečių Naujųjų metų šventimą turime konstatuoti šeimos papročiu ìvairovę, kuri yra reikšmingesnè negu etniniai skirtumai. Kurdami ir dalyvaudami ribinejje metų šventẻje šventès dalyviai siekia pabūti „namie“, tarp artimų žmonių, palaikyti šeimos tradicijas ar kurti naujas. Švente ị vieną grupę sujungia net tik ją švenčiančius žmones. Modernios technologijos sudaro galimybę pasveikinti šventèje nedalyvaujančius giminaičius ar draugus, leidžia išplèsti „švenčiančių kartu“ sąvoką ir kurti „globalius namus“. Pagal situaciją daugiakonfesinèje aplinkoje šventẻ gali burti vienai etninei grupei priklausančius žmones ir formuoti etninio tapatumo jausmus, tačiau daliai bendrijos narių sukūrus etniškai mišrias šeimas ir švenčiant kartu su kitų tautybių draugais, kaimynais ar bendradarbiais - tokios galimybès nelieka.

Vis dèlto gilesnis Naujųjų metų etnografinis tyrimas gali būti reikšmingas Lietuvos kultūros procesų, šeimos ir etniškumo sampratų nagrinèjimui.

\section{Literatūra}

[1] BALYS, Jonas. Lietuvių kalendorinès šventès. Vilnius: Mintis, 1993. 310 p.

[2] BARTH, Fredrik. Introduction. In: Ethnic Groups and Boundaries. The Social Organisation of Culture Difference. Oslo, Bergen: Oslo Universitets Forlaget, 1969, p. 9-38.

(11) Matyt, iš mišrių šeimų. Apie religiją ir tautybę moksleivių neklausème. 
[3] BOISSEVAIN, Jeremy. Inleiding: Identiteit en Feestelijkheid. In: Feest en Ritueel in Europa. Antropologische essays. Eds. Adrianus Kopster, Yme Kuiper and Jojada Verrips. Amsterdam: VU Uitgeverij, 1983, p. 9-14.

[4] DUNDULIENĖ, Pranè. Lietuviu kalendoriniai ir agrariniai papročiai. Vilnius: LTSR aukštojo ir specialiojo vidurinio mokslo ministerija, Vilniaus Darbo Raudonosios Vèliavos ir Draugystès ordinų V. Kapsuko universitetas, 1979. 153 p.

[5] ELISONAS, Jurgis. Burtai Panevežio apskr. rinkti. Tauta ir žodis, 1925, t. 3, p. 349.

[6] ERIKSEN, Thomas Hylland. Akimirkos tironija. Greitasis ir lettasis laikas informacijos amžiuje. Vilnius: Tyto alba, 2004. 199 p.

[7] HOBSBAWM, Eric. Mass-Producting Traditions: Europe, 1870-1914. In: The Invention of Tradition. Eds. E. Hobsbawm, T. Ranger. Cambridge: Cambridge University Press, 1983, p. 263-308. [8] HUGOSON, Marlene. "Instant Tradition": The Introduction of the Swedish Easter Tree. Folklore, 2006, Vol. 117, p. 75-86.

[9] JUCEVIČIUS, Liudvikas Adomas. Raštai. Vilnius: Valstybinè grožinès literatūros 1-kla, 1959. $679 \mathrm{p}$.

[10] KLIMKA, Libertas. Tautos metai. Vilnius: Lietuvos etninès kultūros globos taryba, 2008. 376 p.

[11] KUDIRKA, Juozas. Lietuviškos Küčios ir Kalèdos. Vilnius: Vaga, 1993. 316 p.

[12] LAUČKAITĖ, Laima. Vilniaus šventès ir pramogos prieš Pirmajit pasaulinị karą. Naujasis židinys, 2008, Nr. 11-12, p. 468-475.

[13] MARCINKEVIČIENĖ, Nijolè. Metai už stalo. Kalendoriniu švenčiu ir sezoniniai valgiai. Vilnius: Baltos lankos, 2009. $351 \mathrm{p}$.

[14] MARDOSA, Jonas. Ritualiniai metai šiuolaikinejje Lietuvoje: Miesto ir kaimo perspektyvos. Iš: Šventes moderniame mieste. Festivals in the Modern City. Sud. J. Mardosa. Vilnius: Edukologija, 2013, p. 52-60.

[15] MICKEVIČIUS, Juozas. Žemaičių kalèdų burtai apie ištekèjimą bei vedimą. Gimtasai kraštas, 1941, Nr. 1-2, p. 96-112.

[16] PAUKŠTYTĖ-ŠAKNIENĖ, Rasa. Tradicijos sampratos šiuolaikinëje Lietuvoje. Lituanistica, 2012, Nr. 2(88), p. 206-217.

[17] PETROŠIENĖ, Lina. Glimpses of the Shrovetide Festival in the Early 20th Century Lithuanian Press: How Urbanities Celebrated? In: Šventes mieste / Festivals in the City. Ed. J. Mardosa, Ž. Šaknys. Vilnius: Lietuvos edukologijos universitetas ir Lietuvos istorijos institutas, 2013, p. 21.

[18] SEDAKOVA, Irina. Inventing the Ritual Year in Modern Russia. In: The Ritual Year 3: The Ritual Year and History. Ed. I. Sedakova. Strážnice: Narodni ústav lidové kultury, 2008, p. 51-58.

[19] SENVAITYTĖ, Dalia. Kalendorinių švenčių diskursas sovietinèje Lietuvos periodikoje. I dalis: 1945-1964 metai. Lituanistica, 2013, t. 59, Nr. 2(92), p. 101-121.

[20] SIMPSON, Jacqueline; ROUD, Steve. A Dictionary of English Folklore. Oxford: Oxford University Press, 2000. $412 \mathrm{p}$.

[21] ŠAKNYS, Žilvytis. Jaunimo kalendoriniai papročiai tūkstantmečių sandūroje: Tradicijos ir naujoves. Lietuviu kataliku mokslo akademijos suvažiavimo darbai, 2003, t. 18, p. 165-176.

[22] ŠAKNYS, Žilvytis Bernardas. Kalendoriniai ir darbo papročiai Lietuvoje XIX a. pabaigoje - XX a. pirmoje puseje. Jaunimo vakarèliai. Vilnius: Diemedis, 2001. 156 p.

[23] ŠAKNYS, Žilvytis. 2013. Ritualiniai metai šiuolaikinëje Lietuvoje: Miesto ir kaimo perspektyvos. Iš: Šventes moderniame mieste. Festivals in the Modern City. Sud. J. Mardosa. Vilnius: Edukologija, p. 100-109.

[24] ŠAKNYS, Žilvytis. Jaunimo iniciaciniai ir kalendoriniai papročiai. Iš: R. Paukštytė-Šaknienè, V. Savoniakaitė, Ž. Šaknys, I. Šidiškienè. Lietuvos kultūra. Mažosios Lietuvos ir Žemaitijos papročiai. Vilnius: LII 1-kla, 2012, p. 77-135. 
[25] ŠAKNYS, Žilvytis. Ritual Year in Time and Space: Calendar Customs in North Poland and South Lithuania. In: The Power of Mask. The Ritual Year. 5. Ed. A. Vaicekauskas. Kaunas: Vytautas Magnus University, 2013, p. 108-116.

[26] TOMLINSON, John. Globalizacija ir kultūra. Vilnius: Mintis, 2002. 255 p.

[27] VAICEKAUSKAS, Arūnas. Lietuviu žiemos šventès. Bendruomenès kalendorinio ciklo apeigos XIX a. pab. - XX a. pr. Kaunas: VDU 1-kla, 2005. 192 p.

[28] VAN GENNEP, Arnold. The Rites of Passage. Chicago: The University of Chicago Press, 1960. $198 \mathrm{p}$.

[29] VAN GINKEL, Rob. Celebrating Localism: The Festive Articulation of Texel's Identity. In: Reframing Dutch Culture. Between Otherness and Authentity. Eds. P. J. Margry and H. Roodenburg. Wiltshire: Ashgate, 2007, p. 37-57.

[30] VYŠNIAUSKAITĖ, Angelè. Mūsu metai ir šventès. Kaunas: Šviesa, 1993. 152 p.

[31] ZNAMIEROWSKA-PRÜFFEROWA, Maria. Miestas arčiausia širdies. Vilnius: Alma littera, 2009. 309 p.

ŽILVYTIS ŠAKNYS

\section{Festival in Vilnius: New Year in Lithuanian, Polish and Russian families}

Summary

The aim of the article is to reveal the ethnic and cultural peculiarities of Vilnius citizens via the analysis of the New Year's festival celebrated in the latest years. In order to execute this purpose the composition of the members of the New Year's festival, the place of the festival, the meals, New Year's Day traditions in a family, fortune-telling and the significance of the festival in the structure of a ritual year of Vilnius citizens are compared.

The research has made it evident that a chronological closeness of the festival to Christmas in the structure of a ritual year as well as an exceptional attention to this celebration in the perspective of history enabled the formation of New Year's festival traditions in a family. The stereotypes of the New Year's festival formed in the Soviet period of time as of an exceptional celebration, which embodies the symbolism of a liminal passage rite, are still alive.

The research has proved that it is religion which makes a peculiar (though even a non-direct one) influence on a secular festival. The comparison of the traditions of Lithuanians, Polish and Russians shows that the New Year's festival is far more important to the people of the Russian nationality. However, despite the festival of Old New Year celebrated by the Russians or seeing the New Year in on the Moscow time, the ethnic peculiarity of this festival is not given prominence by the people themselves. The Christian culture functioning in Lithuania, Poland and Russia and a similar structure of a ritual year prevent from essential differences to be revealed. According to the situation in poli-confessional surroundings a festival may unite people belonging to the same ethnic group and form the feelings of ethnic identity. Nevertheless, due to ethnically mixed families among the members of the community or when celebrating the festival together with friends of other nationalities, neighbours or colleagues, such a possibility ceases its existence.

Key words: Vilnius, New Year, festival, Lithuanians, Polish, Russians 